\title{
ASSESSMENT THE VIABILITY PROPERTIES OF LACTOBACILLUS CASEI STRAIN USING LABNEH AS A CARRIER
}

\author{
Kawther El-Shafei ${ }^{1}$, Fouad Mahmoud Fouad Elshaghabee², Hoda Samir El-Sayed ${ }^{1}$, \\ Jihan Mohamed Kassem ${ }^{1 凶}$
}

${ }^{1}$ Dairy Science Department, National Research Centre

El-Bohooth 33, Dokki, Giza, Egypt

2Dairy Science Department, Faculty of Agriculture, Cairo University

12613 Giza, Egypt

\begin{abstract}
Background. Our study was conducted in two stages; the first stage was to examine the fructose fermentation profile by Lactobacillus ( $L$ b.) casei FEGY9973. The second stage was to investigate the viability properties of $L b$. casei either during cold storage of labneh or under simulated gastrointestinal tract (GIT) conditions.

Material and methods. Labneh as a carrier medium was classified into four treatments; the first one contained $2 \%$ free cells of $L b$. casei as a control. The second, third and fourth treatments used $2 \%$ of encapsulated cells of $L b$. case $i$ with different capsule materials, including alginate-milk, sodium alginate and $\kappa$-carrageenan served as $\mathrm{T}_{1}, \mathrm{~T}_{2}$ and $\mathrm{T}_{3}$ respectively. The physiochemical, microbiological and sensory properties of labneh during 15 days of cold storage were shown. Moreover, the viability of free and encapsulated Lb. casei subjected to some manufacturing and simulated GIT conditions was tested.

Results. It was revealed that lactate was the major metabolite in the medium for colonic fermentation, whereas no amounts of ethanol could be detected. Moreover, labneh samples including free cells of $L b$. casei had lower $\mathrm{pH}$ values than treatments containing microcapsules of $L b$. casei. The levels of moisture, acetaldehyde and diacetyle in treatments with different encapsulated materials were increased during the cold storage period. Accordingly, labneh samples with encapsulated $L b$. casei had higher sensory scores than the control. In addition, labneh samples with $L b$. casei in milk-alginate microcapsules showed a high viability during cold storage and under simulated GIT conditions. A significant decrease in the viability of free or encapsulated Lb. case $i$ was observed at 15 days of cold storage.

Conclusion. Encapsulated Lb. casei by alginate-milk was more resistant during the cold storage period and under simulated gastric conditions than the other two treatments.
\end{abstract}

Keywords: novel lactobacilli strains, alginate-milk microcapsules, labneh, simulated gastric conditions, functional dairy foods

\section{INTRODUCTION}

The issue of diet and health has recently come to global attention. Probiotic live bacteria are known as good or friendly bacteria and are known to minimize potentially harmful bacteria from the intestine (Gillian,
2008). Probiotic food are defined as "food containing live microorganisms, which actively promote health of consumers by ameliorative the balance of micro-flora in the gut when ingested live in adequate numbers"

『jihankasem@yahoo.com 
(Fuller, 1992; Shah, 2004). Food providing these microorganisms may be considered functional food, i.e., as well as nourishing the body, these products have biologically active components that participate in the maintenance of good health and wellness, while decreasing the risk of diseases (Mohammadi and Mortazavian, 2011; Saad et al., 2013). Eighty types of dairy products containing probiotic cultures have been produced around the world for many years (Maity et al., 2008).

Several criteria have been performed to select different probiotic microorganisms. These include biosafety, viability during different manufacture conditions, acid and bile resistance and confer different health benefits e.g. enhancing the immune system, reducing levels of cholesterol and reducing the risk of cancer (Tuomola et al., 2001; Shewale et al., 2014). However, there is still a need to develop new criteria for probiotics in order to increase their application in food and nutraceutical products. Therefore, we investigate the fermentation profile of fructose by testing the $L b$. casei strain, because fructose is used as a sweetener (Hanover and White, 1993) and it accumulates significantly in the intestine, resulting in increased levels of endogenous ethanol and lipid formation in liver tissues, causing non-alcoholic fatty liver disease (NAFLD) (Tran et al., 2009).

Labneh (concentrated yoghurt) is a popular fermented milk product in the Middle East, while and its nutritional and therapeutic properties are considered to be better than those of yoghurt; it has 2.5 times higher protein content, $50 \%$ more minerals and larger numbers of viable starter cultures than yoghurt (Nsabimana et al., 2005). In order for labneh to be recognized as probiotic carrier foods, appropriate probiotic microorganisms were added to retain sufficient quantities through all the stages of the process. Furthermore, labneh contains higher total solids than yoghurt; therefore it may be considered a suitable matrix for probiotics, since it also offers protection for them during transit through the gastrointestinal tract (GIT) (Abd El-Salam et al., 2011). Different compositional and process factors have an adverse effect on the viability of probiotics in labneh, including $\mathrm{pH}$, redox potential, the level of probiotic inoculation, flavoring supplementation, microbiota competition, and the possible presence of bacteriocins or other antimicrobials, incubation and storage temperature, salt \& water activity and packaging materials. It also becomes clear from data that the viability of probiotics is due to its strain type (Castro et al., 2015; Rocha et al., 2014).

Microencapsulation provides a physical barrier against harsh environmental conditions, and results in improved viability of probiotics (Champagne and Kailasapathy, 2008). Different materials have been applied to enhance the survival of different strains of probiotics during refrigerated storage of dairy products and during GIT transit, such as gelatin (Shah, 2000), fats (Situ-Cruce and Goulet, 2001), к-carrageenan (Adhikari et al., 2003), sodium alginate (El-Dieb et al., 2012; Krasaekoopt et al., 2004), different polysaccharides including guar gum, arabic gum and chitosan (Elshaghabee, 2016a).

Lactobacillus (Lb.) casei represents a high biodiversity species of genus Lactobacillus. It has been isolated from different niches, such as fermented food, and human and animal intestines (Claesson et al., 2007). Lb. casei is also a dominant species of non-starter lactic acid bacteria (NSLAB) in different types of ripening cheese, like Cheddar cheese (Gobbeti et al., 2015), and plays an important role in the development of flavors in these products (Swearingen et al., 2001; Van Hoorde et al., 2010).

Therefore, the aim of this study was to compare the impact of different capsule materials (alginate-milk, sodium alginate and $\kappa$-carrageenan) on the viability properties of novel isolate of $L b$. casei FEGY9973 subjected to some manufacturing conditions and simulated GIT conditions, using labneh as a delivery vehicle for it in order to apply probiotic labneh in the diet of NAFLD patients in our future study.

\section{MATERIAL AND METHODS}

\section{Milk}

Fresh buffalo milk was obtained from the herd at the Faculty of Agriculture, Cairo University, Giza, Egypt.

\section{Probiotic strain}

Freeze-dried Lb. casei FEGY 9973 was obtained from our culture collection, Department of Dairy Science, Faculty of Agriculture, Cairo University, Egypt. 


\section{Starter culture}

Lactobacillus (Lb.) delbrueckii subsp. bulgaricus Lb-12 DRI-VAC was provided from Northern Regional Research Laboratory (NRRL), Illinois, USA. Streptococcus $(S$.) thermophilus $\mathrm{CH}-1$ obtained from Chr. Hansens's Lab., Copenhagen, Denmark.

\section{Fermentation of fructose}

Fermentation was performed in media for colonic bacteria (MCB) at $37^{\circ} \mathrm{C}$ in an anaerobic jar (Oxoide, Yorkshire, UK). The medium composition $\left(\mathrm{g} \cdot \mathrm{L}^{-1}\right)$ was prepared according to the procedure described by Van der Meulen et al. (2006). For metabolite analysis, one $\mathrm{mL}$ of culture (max. $\mathrm{OD}_{620 \mathrm{~nm}}=1.35 \pm 0.12$ ) was mixed with $10 \mu \mathrm{L}$ Carrez I and $10 \mu \mathrm{L}$ Carrez II solution and centrifuged at $14000 \mathrm{xg}$ for $10 \mathrm{~min}$ at $4^{\circ} \mathrm{C}$. The clarified layer was separated and filtered through a $0.2 \mu \mathrm{m}$ membrane filter. The metabolite samples were analyzed using HPLC system according to the procedure described by Elshaghabee et al. (2016b).

\section{Cultivation and harvesting of $L b$. casei FEGY 9973 cells}

MRS broth (Oxoid, Yorkshire, UK) was used to prepare the cell suspensions for $L b$. casei. The medium which was inoculated with $2 \%$ active $L b$. casei cells and incubated at $37^{\circ} \mathrm{C}$ for $48 \mathrm{~h}$. Cells were harvested by centrifugation at $5000 \mathrm{rpm}$ for $15 \mathrm{~min}$, and the cells were washed twice with saline and then used to prepare capsules.

\section{Encapsulation of $L b$. casei FEGY 9973 by alginate-milk}

Milk (total solids $11 \%$ ) and sodium alginate (4\%) were sterilized for $15 \mathrm{~min}$ at 110 and $121^{\circ} \mathrm{C}$, respectively. The $L b$. casei cells were added to the milk and sodium alginate to make a mixture containing $1: 1: 1 \mathrm{w} / \mathrm{w}$. The mixture was then dropped into $100 \mathrm{mM} \mathrm{CaCl}_{2}$ while gently stirring $(100 \mathrm{rpm})$, microspheres formed and solidified in $\mathrm{CaCl}_{2}$ solution for 30 min according to the procedure described by Shi et al. (2013).

\section{Encapsulation of $L b$. casei FEGY 9973 by alginate}

A suspension of cells was mixed with an equal volume of sodium alginate $(4 \%)$. The mixture was added drop-wise into a solution of sodium chloride $(0.2 \mathrm{~mol} / \mathrm{L})$ and calcium chloride $\left(0.5 \mathrm{mmol} \cdot \mathrm{L}^{-1}\right)$ and magnetically stirred at $200 \mathrm{rpm} / \mathrm{min}$ until alginate beads were formed, in accordance with the procedure described by Klinkenberg et al. (2001).

\section{Encapsulation of $L b$. casei FEGY 9973 by $\kappa$-carrageenan}

A mixture was prepared by mixing $20 \mathrm{~g}$ cells in $1000 \mathrm{ml}$ of a sterile solution of $\kappa$-carrageenan $(2 \%)$, then the mixture was added drop-wise into $\mathrm{KCl}(3 \%)$ under agitation. Carrageenan beads were formed within $10 \mathrm{~min}$, as described by Dinakar and Mistry (1994).

\section{Manufacturing of labneh}

First, the starter cultures of yoghurt (Lactobacillus delbrueckii subsp. bulgaricus and Streptococcus thermophilus) were activated individually in skimmed milk by inoculating skimmed milk with $2 \%$ lyophilized strains and incubating it at $37^{\circ} \mathrm{C}$ for $24 \mathrm{~h}$ before production of labneh. Then, labneh was made using the method described by Mohamed et al. (2013) with some modifications. Fresh buffalo's milk was heated $\left(90^{\circ} \mathrm{C} / 15 \mathrm{~min}\right)$, cooled to $40^{\circ} \mathrm{C}$ then inoculated with $2 \%$ of propagated culture of $L b$. delbrueckii subsp. bulgaricus $\mathrm{Lb}-12$ DRI-VAC and $S$. thermophilus $\mathrm{CH}-1$ in skimmed milk. The inoculated milk was divided into four equal portions. The first served as a control fortified with $2 \%$ free cells of $L b$. casei (C). The second, third and fourth portions were fortified with the same ratio $(2 \%)$ of encapsulated $L b$. casei by alginate-milk, alginate and $\kappa$-carrageenan, respectively $\left(\mathrm{T}_{1}, \mathrm{~T}_{2}\right.$ and $\left.\mathrm{T}_{3}\right)$. All portions were incubated at $40^{\circ} \mathrm{C}$ until complete coagulation occurred. The labneh was cooled to a temperature of $10^{\circ} \mathrm{C}$ overnight, stirred and strained using a cheese cloth, which was hung in the refrigerator at $4^{\circ} \mathrm{C}$ to allow whey drainage for $12 \mathrm{~h}$. The plastic containers stored at $\left(7^{\circ} \mathrm{C} \pm 2\right)$ for 15 days. Treatment samples of labneh were analyzed for their chemical properties and microbiological examination when fresh and during storage.

\section{Physicochemical properties of labneh}

The $\mathrm{pH}$ values of labneh samples were measured during the storage period using a digital laboratory $\mathrm{pH}$ meter (HI 93 1400, Hanna instruments, Woonsocket, Rhode Island, USA) with a glass electrode. The moisture content of the treatment samples was also determined when fresh, 7 and 15 days according to AOAC 
(2012). To follow up on flavor progress, acetaldehyde content $\left(\mathrm{mmol} \cdot 100 \mathrm{~g}^{-1}\right)$ was estimated in accordance with the procedure described by Lee and Jago (1969) and diacetyl content $\left(\mathrm{mmol} \cdot 100 \mathrm{~g}^{-1}\right)$ was determined as reported by Pack et al. (1964).

\section{Simulated gastric juice (SGJ) tolerance}

A SGJ solution was prepared as described by Shi et al. (2013). One gram of labneh samples contained encapsulated $L b$. casei strains with different materials mixed in $10 \mathrm{~mL}$ of SGJ and incubated for $30,60,90$ and $120 \mathrm{~min}$ at $37^{\circ} \mathrm{C}$. The viability of bacterial cells was detected using pour plate counts in MRS agar free from sugar and supplemented with $0.05 \%$ cellobiose as a carbon source and incubated at $37^{\circ} \mathrm{C}$ in anaerobic conditions.

\section{Simulated intestinal juice (SIJ) tolerance}

A SIJ solution was prepared according to Shi et al.'s (2013) procedure. One gram of the labneh sample contained encapsulated $L b$. casei with different materials mixed with $10 \mathrm{~mL}$ of SGJ and incubated at the same time and temperature. The viability of the bacteria strain was determined according to the procedure described by Shi et al. (2013) and El-Sayed et al. (2017).

\section{Microbiological analysis}

Counts of Lb. bulgaricus, St. thermophilus and $L b$. case $i$ were determined using MRS agar according to the procedure described by De Man et al. (1960), M17 agar (Terzaghi and Sandine, 1975) and MRS agar free from sugar and supplemented with $0.05 \%$ cellobiose as a carbon source (Shah, 2000). Plates of Lb. delbrueckii subsp. bulgaricus, Streptococcus thermophilus and $L b$. casei were incubated at $37^{\circ} \mathrm{C}$ for $48 \mathrm{~h}$ and under anaerobic conditions for both lactobacilli strains.

\section{Statistical analysis}

Samples were made in triplicate. The mean was then calculated from these triplicate analyses. Data were presented as the overall mean for the two trials. Statistical analysis for the data obtained was carried out using analysis of variance (ANOVA) and Duncan tests with the Statistical Analysis System (SAS, 1994). A probability of $P<0.05$ was used to establish the statistical significance.

\section{RESULTS AND DISCUSSION}

\section{Fermentation profile of fructose fermentation by $L$ b. casei FEGY 9973}

Lactate was the major metabolite of fermentation of fructose by $L b$. casei FEGY9973 after $18 \mathrm{~h}$ of the fermentation period. The concentration of lactate was $42.05 \pm 1.25 \mathrm{mM}$ (Elshaghabee et al., 2016b), whereas the concentration of fermented fructose was $41.85 \mathrm{mM}$. Lb. casei is a facultative hetero-fermentative LAB (Kandler and Weiss, 1986; Mayra-Makinen and Bigret, 1998). Facultative hetero-fermentative $L b$. casei showed homolactic fermentation of hexoseslike fructose similar to facultative hetero-fermentative Lb. plantarum 92380 as reported by Kleerebezem et al. (2003) and Axelsson (2004). The fermentation of fructose by microencapsulated $L b$. casei was not tested, because the cells of different lactobacilli strains were released from their capsules, as previously investigated by Iyer et al. (2005) and Mandal et al. (2006; 2014).

\section{Physicochemical properties of labneh during cold storage}

Labneh samples were evaluated for moisture content when fresh and during storage in Table 1 data revealed that there were no significant differences $(P>0.05)$ between fresh samples in either the control or treatments. It was also obvious that using capsulate materials such as alginate, carrageenan have the ability to hold water more than free cells. So, the control samples of labneh that contained free cells had a slight lower moisture content than encapsulated samples when fresh and through the storage period. There were no differences in moisture content observed between the capsulated materials which were used. Increased storage period moisture content decreased in all labneh samples. These findings were in accordance with Al Otaibi and El Demerdash (2008), who illustrated that total solid contents of labneh slightly increased as the storage period increased. Moreover, the same results were produced by El-Gizawy et al. (2013), who found that the moisture content of kareish cheese decreased as the storage period increased and kareish cheese manufactured with microencapsulated $L b$. bulgaricus had a high moisture content throughout the storage period compared to the control samples. 
El-Shafei, K., Elshaghabee, F. M. F., El-Sayed, H. S., Kassem, J. M. (2018). Assessment the viability properties of Lactobacillus casei strain using labneh as a carrier. Acta Sci. Pol. Technol. Aliment., 17(3), 267-276. http://dx.doi.org/10.17306/J.AFS.2018.0583

Table 1. Changes in $\mathrm{pH}$ values and physico-chemical properties of labneh during cold storage $\left(7^{\circ} \mathrm{C} \pm 2\right)$

\begin{tabular}{|c|c|c|c|c|c|}
\hline \multirow{2}{*}{$\begin{array}{l}\text { Treatments } \\
\text { (T) }\end{array}$} & \multirow{2}{*}{$\begin{array}{c}\text { Storage } \\
\text { period } \\
\text { days }\end{array}$} & \multicolumn{4}{|c|}{ Physico-chemical parameters } \\
\hline & & $\mathrm{pH}$ & $\begin{array}{c}\text { moisture } \\
\%\end{array}$ & $\begin{array}{l}\text { acetaldehyde } \\
\mu \mathrm{mol} \cdot 100 \mathrm{~g}^{-1}\end{array}$ & $\begin{array}{c}\text { diacetyle } \\
\mu \mathrm{mol} \cdot 100 \mathrm{~g}^{-1}\end{array}$ \\
\hline \multirow[t]{3}{*}{ Control } & fresh & $4.78 \pm 0.21^{\mathrm{A}}$ & $72.41 \pm 0.31^{\mathrm{B}}$ & $20.24 \pm 2.15^{\mathrm{F}}$ & $6.84 \pm 2.51^{\mathrm{H}}$ \\
\hline & 7 & $3.96 \pm 0.24^{\mathrm{B}}$ & $72.10 \pm 0.25^{\mathrm{C}}$ & $30.12 \pm 1.56^{\mathrm{C}}$ & $11.46 \pm 1.47^{\mathrm{E}}$ \\
\hline & 15 & $3.73 \pm 0.15^{\mathrm{D}}$ & $71.96 \pm 0.21^{\mathrm{D}}$ & $28.75 \pm 1.53^{\mathrm{D}}$ & $12.90 \pm 1.51^{\mathrm{D}}$ \\
\hline \multirow[t]{3}{*}{$\mathrm{T}_{1}$} & fresh & $4.82 \pm 0.18^{\mathrm{A}}$ & $72.89 \pm 0.27^{\mathrm{A}}$ & $21.45 \pm 1.37^{\mathrm{E}}$ & $8.36 \pm 1.71^{\mathrm{G}}$ \\
\hline & 7 & $4.02 \pm 0.20^{\mathrm{A}}$ & $73.02 \pm 0.25^{\mathrm{A}}$ & $33.77 \pm 1.45^{\mathrm{A}}$ & $15.94 \pm 2.31^{\mathrm{C}}$ \\
\hline & 15 & $3.65 \pm 0.21^{\mathrm{DE}}$ & $73.13 \pm 0.41^{\mathrm{A}}$ & $30.96 \pm 2.11^{\mathrm{C}}$ & $17.32 \pm 1.51^{\mathrm{B}}$ \\
\hline \multirow[t]{3}{*}{$\mathrm{T}_{2}$} & fresh & $4.71 \pm 0.19^{\mathrm{A}}$ & $72.79 \pm 0.35^{\mathrm{B}}$ & $21.64 \pm 1.58^{\mathrm{E}}$ & $9.01 \pm 2.81^{\mathrm{F}}$ \\
\hline & 7 & $3.99 \pm 0.21^{\mathrm{B}}$ & $72.95 \pm 0.28^{\mathrm{A}}$ & $32.88 \pm 2.20^{\mathrm{B}}$ & $16.43 \pm 1.50^{\mathrm{C}}$ \\
\hline & 15 & $3.74 \pm 0.16^{\mathrm{D}}$ & $73.07 \pm 0.24^{\mathrm{A}}$ & $30.25 \pm 1.75^{\mathrm{C}}$ & $19.03 \pm 1.09^{\mathrm{A}}$ \\
\hline \multirow[t]{3}{*}{$\mathrm{T}_{3}$} & fresh & $4.75 \pm 0.18^{\mathrm{A}}$ & $72.74 \pm 0.35^{\mathrm{B}}$ & $20.95 \pm 2.01^{\mathrm{F}}$ & $8.85 \pm 1.65^{\mathrm{G}}$ \\
\hline & 7 & $3.81 \pm 0.15^{\mathrm{C}}$ & $72.99^{\mathrm{A}}$ & $33.40 \pm 1.89^{\mathrm{A}}$ & $16.10 \pm 0.95^{\mathrm{C}}$ \\
\hline & 15 & $3.78 \pm 0.14^{\mathrm{D}}$ & $73.12^{\mathrm{A}}$ & $30.56 \pm 3.01^{\mathrm{C}}$ & $18.93 \pm 1.21^{\mathrm{A}}$ \\
\hline
\end{tabular}

Treatments: control - labneh manufactured with free cells of Lactobacillus (Lb.) casei FEGY9973, $\mathrm{T}_{1}$ - labneh manufactured with $2 \%$ of alginate-milk microcapsules containing $L b$. casei FEGY9973, $\mathrm{T}_{2}-$ labneh manufactured with $2 \%$ of alginate microcapsules containing $L b$. casei FEGY9973, $\mathrm{T}_{3}$ - labneh manufactured with $2 \%$ of $\kappa$-carrageenan microcapsules containing $L b$. casei FEGY9973.

Changes in the $\mathrm{pH}$ values of labneh samples are presented in the same table. As expected, the $\mathrm{pH}$ values in all samples decreased through the storage period. The $\mathrm{pH}$ values of the control samples reduced from 4.78 in fresh samples to 3.73 at the end of storage. But the decrease in the first week was significantly $(P<$ 0.05 ) more pronounced than that in the second one, while all treated samples were slightly more decreased in $\mathrm{pH}$ values than in control samples. These results coincide with microbiological data, which indicated that the viability of both starter culture counts was raised in the first week then decreased at the end of storage period. Similarly, viable counts of $L b$. casei showed same trend as starter cultures, but all encapsulated treatments were more viable than free cells. Thus, the acidity in all samples was due to the activity of both the starter cultures and $L b$. casei. The same trend was observed by Dzigbordi et al. (2013), who stated that the $\mathrm{pH}$ of yoghurt samples decreased as the storage period extended. Likewise, El-Gizawy et al. (2013) showed that the $\mathrm{pH}$ values of fresh kareish cheese with microencapsulated $L b$. bulgaricus significantly decreased during the storage period. Kareish cheese samples with microencapsulated $L b$. bulgaricus also had lower $\mathrm{pH}$ values compared with the controls.

The flavor compounds (acetaldehyde and diacetyl) of labneh samples during cold storage are presented in Table 1. Acetaldehyde was produced as a result of the presence of both starter cultures and $L b$. casei. These microorganisms can ferment milk lactose to lactic acid, acetaldehyde and diacetyl (Amarita et al., 2001; Hamdan et al., 1971). Furthermore, the levels of acetaldehyde were increased during the first 7 days of the storage period then decreased gradually at the end of cold storage. The increase in acetaldehyde in the first 7 days could be due to the activity of the threonine aldolase enzyme detected in starter cultures, which converts threonine to acetaldehyde and glycine, as previously found by Al Otaibi and El Demerdash (2008). Zareba et al. (2014) explained that acetaldehyde could 
be reduced and converted to ethanol. On the other hand, the levels of acetaldehyde in treatments, while Lb. case $i$ was in an encapsulated form, were significantly higher than in the controls during the storage period. These data could be due to the viability of encapsulated $L b$. casei in different capsule materials more than the control, as shown in microbiological results.

The levels of diacetyl in the labneh samples showed a different trend compared to acetaldehyde in the storage period, whereas levels of diacetyle values were significantly $(p<0.05)$ increased until the end of storage period (Table 1). Our data are in agreement with the results obtained by Mohamed et al. (2015), where levels of diacetyl increased during fifteen days of cold storage of labneh compared to acetaldehyde contents in the samples.

\section{Viability of starter culture in labneh during storage periods}

The data in Table 2 show that the counts of both starter cultures (Lactobacillus delbrueckii subsp. bulgaricus and $S$. thermophilus) were significantly $(p<0.05)$ increased in labneh samples at the first week then decreased significantly at the end in all treatments. The viable counts of Lb. delbrueckii subsp. bulgaricus ranged between 7.95 and $8.26 \log \mathrm{CFU} / \mathrm{g}$ in all treatments when fresh and reached between 8.19 and $8.31 \log \mathrm{CFU} / \mathrm{g}$ at the end. Data also indicated that $\mathrm{T}_{2}$ samples were significant $(P<0.05)$ and had the highest viable counts of $L b$. bulgaricus. Similar results were observed for S. thermophilus, in which the viable counts ranged between 7.27 and $8.09 \log \mathrm{CFU} / \mathrm{g}$ in all treatments when fresh and between 7.60 and $8.75 \log \mathrm{CFU} / \mathrm{g}$ at the end of the progress. Moreover, the results showed that there were slight differences between the control and treatments that contained encapsulated probiotics with different materials. The results obtained by El-Sayed et al. (2017) stated that both starter cultures counts were increased in yoghurt samples in the first 5 days and then there was a small decline at the end of the storage period.

\section{Viability of $L b$. casei FEGY 9973 in labneh during storage periods}

Differences in viable counts of encapsulated $L b$. case $i$ in labneh treatment samples during storage are presented in Table 3. Viable counts of $L b$. case $i$ were increased in the first 7 days of storage and decreased significantly at the end of storage. Moreover, the viable counts in treatment samples contained more encapsulated $L b$. casei than the control (free cells), especially in $\mathrm{T}_{1}$, which used alginate-milk as a coating material, and in which the viable count increased more than $\log 9$ cycles at the end compared with the control. This increase shows the protecting effect of encapsulation on the survival rate of Lb. casei. These results were in agreement with those obtained by Godward and Kailasapathy (2003). Jayalalitha et al. (2011), showed also that the encapsulated probiotic count in yoghurt was significantly greater than in the control in each week of the storage period.

Table 2. Viable counts of starter cultures in labneh during cold storage $\left(7^{\circ} \mathrm{C} \pm 2\right)$

\begin{tabular}{|c|c|c|c|c|c|c|}
\hline \multirow{3}{*}{$\begin{array}{l}\text { Treatments } \\
\text { (T) }\end{array}$} & \multicolumn{3}{|c|}{ Lb. bulgaricus } & \multicolumn{3}{|c|}{ St. thermophiles } \\
\hline & \multicolumn{6}{|c|}{ storage periods, days } \\
\hline & fresh & 7 & 15 & fresh & 7 & 15 \\
\hline Control & $7.95 \pm 0.60^{\mathrm{H}}$ & $8.38 \pm 0.52^{\mathrm{BCD}}$ & $8.19 \pm 0.62^{\mathrm{F}}$ & $8.09 \pm 0.55^{\mathrm{CD}}$ & $8.43 \pm 0.51^{\mathrm{B}}$ & $8.34 \pm 0.70^{\mathrm{BC}}$ \\
\hline $\mathrm{T}_{1}$ & $8.19 \pm 0.53^{\mathrm{F}}$ & $8.50 \pm 0.71^{\mathrm{A}}$ & $8.31 \pm 0.56^{\mathrm{DE}}$ & $7.65 \pm 0.82^{\mathrm{E}}$ & $7.82 \pm 0.54^{\mathrm{DE}}$ & $7.60 \pm 0.57^{\mathrm{E}}$ \\
\hline $\mathrm{T}_{2}$ & $8.26 \pm 0.74^{\mathrm{EF}}$ & $8.48 \pm 0.81^{\mathrm{AB}}$ & $8.44 \pm 0.75^{\mathrm{ABC}}$ & $7.27 \pm 0.59^{\mathrm{F}}$ & $7.72 \pm 0.87^{\mathrm{E}}$ & $8.30 \pm 0.80^{\mathrm{BC}}$ \\
\hline $\mathrm{T}_{3}$ & $8.08 \pm 0.83^{\mathrm{G}}$ & $8.36 \pm 0.65^{\mathrm{CDE}}$ & $8.31 \pm 0.92^{\mathrm{DE}}$ & $7.88 \pm 1.15^{\mathrm{DE}}$ & $7.95 \pm 0.82^{\mathrm{DE}}$ & $8.75 \pm 0.90^{\mathrm{A}}$ \\
\hline
\end{tabular}

Treatments: control - labneh manufactured with free cells of Lactobacillus (Lb.) casei FEGY9973, $\mathrm{T}_{1}$ - labneh manufactured with $2 \%$ of alginate-milk microcapsules containing $L b$. casei FEGY9973, $\mathrm{T}_{2}$ - labneh manufactured with $2 \%$ of alginate microcapsules containing $L b$. casei FEGY9973, $\mathrm{T}_{3}$ - labneh manufactured with $2 \%$ of $\kappa$-carrageenan microcapsules containing $L b$. casei FEGY9973. 
El-Shafei, K., Elshaghabee, F. M. F., El-Sayed, H. S., Kassem, J. M. (2018). Assessment the viability properties of Lactobacillus casei strain using labneh as a carrier. Acta Sci. Pol. Technol. Aliment., 17(3), 267-276. http://dx.doi.org/10.17306/J.AFS.2018.0583

Table 3. Viable counts of Lb. casei FEGY9973 in labneh during cold storage $\left(7^{\circ} \mathrm{C} \pm 2\right)$

\begin{tabular}{cccc}
\hline \multirow{2}{*}{$\begin{array}{c}\text { Treatments } \\
(\mathrm{T})\end{array}$} & \multicolumn{3}{c}{ Storage periods, days } \\
\cline { 2 - 4 } & fresh & 7 & 15 \\
\hline Control & $8.11 \pm 0.55^{\mathrm{FG}}$ & $8.55 \pm 0.58^{\mathrm{E}}$ & $7.86 \pm 0.60^{\mathrm{G}}$ \\
$\mathrm{T}_{1}$ & $9.75 \pm 0.72^{\mathrm{A}}$ & $9.93 \pm 0.59^{\mathrm{C}}$ & $9.46 \pm 0.80^{\mathrm{BC}}$ \\
$\mathrm{T}_{2}$ & $9.00 \pm 0.65^{\mathrm{D}}$ & $9.67 \pm 0.81^{\mathrm{AB}}$ & $9.35 \pm 0.68^{\mathrm{C}}$ \\
$\mathrm{T}_{3}$ & $8.77 \pm 0.77^{\mathrm{DE}}$ & $8.70 \pm 0.69^{\mathrm{E}}$ & $8.20 \pm 0.72^{\mathrm{F}}$ \\
\hline
\end{tabular}

Treatments: control - labneh manufactured with free cells of Lactobacillus (Lb.) casei FEGY9973, $\mathrm{T}_{1}$ - labneh manufactured with $2 \%$ of alginate-milk microcapsules containing $L b$. casei FEGY9973, $\mathrm{T}_{2}$ - labneh manufactured with $2 \%$ of alginate microcapsules containing $L$ b. casei FEGY9973, $\mathrm{T}_{3}$ - labneh manufactured with $2 \%$ of $\kappa$-carrageenan microcapsules containing Lb. casei FEGY9973.

\section{Viability of $L b$. casei FEGY 9973 in labneh when exposed to SGJ}

The microencapsulation process offers protection to probiotic cells during exposure to SGJ for $120 \mathrm{~min}$ as in Table 4. The viability of free $L b$. casei in labneh was

Table 4. Viability of Lb. casei FEGY9973 in labneh when exposed to simulated gastric juice (SGJ)

\begin{tabular}{ccccc}
\hline \multirow{2}{*}{$\begin{array}{c}\text { Treatments } \\
(\mathrm{T})\end{array}$} & 30 & 60 & 90 & 120 \\
\cline { 2 - 5 } & 7.99 & 7.07 & 5.41 & 3.40 \\
Control & $\pm 0.81^{\mathrm{C}}$ & $\pm 0.67^{\mathrm{E}}$ & $\pm 0.77^{\mathrm{I}}$ & $\pm 0.58^{\mathrm{L}}$ \\
& 9.71 & 8.84 & 7.90 & 6.05 \\
$\mathrm{~T}_{1}$ & $\pm 0.69^{\mathrm{A}}$ & $\pm 0.71^{\mathrm{B}}$ & $\pm 0.63^{\mathrm{C}}$ & $\pm 1.02^{\mathrm{G}}$ \\
& 8.93 & 7.30 & 6.75 & 5.03 \\
$\mathrm{~T}_{2}$ & $\pm 0.74^{\mathrm{B}}$ & $\pm 0.92^{\mathrm{D}}$ & $\pm 0.83^{\mathrm{F}}$ & $\pm 0.91^{\mathrm{J}}$ \\
& 8.80 & 7.04 & 5.61 & 4.35 \\
$\mathrm{~T}_{3}$ & $\pm 0.88^{\mathrm{B}}$ & $\pm 0.85^{\mathrm{E}}$ & $\pm 0.93^{\mathrm{H}}$ & $\pm 0.75^{\mathrm{K}}$ \\
\hline
\end{tabular}

Treatments: control - labneh manufactured with free cells of Lactobacillus (Lb.) casei FEGY9973, $\mathrm{T}_{1}$ - labneh manufactured with $2 \%$ of alginate-milk microcapsules containing $L b$. casei FEGY9973, $\mathrm{T}_{2}$ - labneh manufactured with $2 \%$ of alginate microcapsules containing $L b$. casei FEGY9973, $\mathrm{T}_{3}-$ labneh manufactured with $2 \%$ of $\kappa$-carrageenan microcapsules containing Lb. casei FEGY9973. reduced more than $4.50 \log$ cycles after $120 \mathrm{~min}$. On the other hand, encapsulation with alginate-milk offered protection when exposed to SGJ, whereas the viability of encapsulated $L b$. case $i$ by alginate-milk $\left(\mathrm{T}_{1}\right)$ decreased around $3 \log$ cycles only after $120 \mathrm{~min}$, followed by $\mathrm{T}_{2}$, which dropped to around $3.80 \log$ cycles compared with control.

This increment of viability of $L b$. casei in labneh may be attributed to the materials that used in the capsulation technique. The results obtained by Jayalalitha et al. (2011), El-Shafei et al. (2015) and Elshaghabee et al. (2016a) demonstrated that different methods of encapsulation had enhanced the viability of lactobacilli, bifidobacteria and $S$. thermophilus against simulated gastrointestinal conditions.

\section{Viability of $L b$. casei FEGY 9973 in labneh when exposed to SIJ}

The viability of free and encapsulated $L b$. casei FEGY9973 with different materials when exposed to SIJ are shown in Table 5. The data indicate that the viability of free culture in labneh was reduced more than $2.7 \log$ cycles after $120 \mathrm{~min}$. On the contrary, encapsulated $L b$. casei in labneh was more stable than

Table 5. Viability of $L b$. casei FEGY9973 in labneh when exposed to simulated intestinal juice (SIJ)

\begin{tabular}{ccccc}
\hline \multirow{2}{*}{$\begin{array}{c}\text { Treatments } \\
(\mathrm{T})\end{array}$} & 30 & 60 & 90 & 120 \\
\cline { 2 - 5 } & 8.23 & 7.50 & 6.70 & 5.50 \\
Control & $\pm 0.95^{\mathrm{D}}$ & $\pm 0.88^{\mathrm{F}}$ & $\pm 0.69^{\mathrm{G}}$ & $\pm 0.81^{\mathrm{I}}$ \\
& 9.81 & 9.10 & 8.78 & 8.10 \\
$\mathrm{~T}_{1}$ & $\pm 0.85^{\mathrm{A}}$ & $\pm 0.58^{\mathrm{B}}$ & $\pm 0.78^{\mathrm{C}}$ & $\pm 0.62^{\mathrm{DE}}$ \\
& 9.16 & 8.26 & 7.51 & 6.35 \\
$\mathrm{~T}_{2}$ & $\pm 0.71^{\mathrm{B}}$ & $\pm 0.75^{\mathrm{D}}$ & $\pm 0.91^{\mathrm{F}}$ & $\pm 0.63^{\mathrm{H}}$ \\
& 8.85 & 7.90 & 6.29 & 5.46 \\
$\mathrm{~T}_{3}$ & $\pm 0.90^{\mathrm{C}}$ & $\pm 0.82^{\mathrm{E}}$ & $\pm 68^{\mathrm{H}}$ & $\pm 0.83^{\mathrm{I}}$ \\
\hline
\end{tabular}

Treatments: control - labneh manufactured with free cells of Lactobacillus (Lb.) casei FEGY9973, $\mathrm{T}_{1}$ - labneh manufactured with $2 \%$ of alginate-milk microcapsules containing $L b$. casei FEGY9973, $\mathrm{T}_{2}$ - labneh manufactured with $2 \%$ of alginate microcapsules containing $L b$. casei FEGY9973, $\mathrm{T}_{3}$ - labneh manufactured with $2 \%$ of $\kappa$-carrageenan microcapsules containing Lb. casei FEGY9973. 
free cultures during exposure to SIJ for $120 \mathrm{~min}$, and the viability of encapsulated $L b$. casei reduced only $1.70 \log$ cycles for $\mathrm{T}_{1}$ as compared to the initial counts. Moreover, the $\mathrm{T}_{3}$ sample did not differ from the control when exposed to SIJ for 120 min compared to the initial counts. Alginate-milk microspheres could give more resistance from the effect of bile salt for probiotic free cells (Ding and Shah, 2007; El-Sayed et al., 2017; Kailasapathy, 2006).

\section{CONCLUSION}

Supplementation of different traditional dairy products with probiotics contributes to improving the health status of consumers. In our study, we evaluated the viability properties of a new strain of $L b$. casei FEGY9973 under cold storage and simulated gastric conditions using labneh as a matrix. $L b$. casei exhibits homo-lactic fermentation under anaerobic conditions, whereas lactate was the major metabolite. Further proteomics analysis for the fermentation profile of fructose by $L b$. casei are needed. Labneh samples containing $L b$. casei in milk-alginate microcapsules showed a high viability under simulated GIT conditions and during cold storage with a high concentration of acetaldehyde and diacetyl. Moreover, application of encapsulated cells of $L b$. casei could protect labneh from drying during the storage period.

\section{REFERENCES}

Abd El-Salam, M. H., Hippen, A. R., El-Shafie, K., Assem, F. M., Abbas, H., Abd El-Aziz, M., ..., El-Aassar, M. (2011). Preparation and properties of probiotic concentrated yoghurt (Labneh) fortified with conjugated linoleic acid. Int. J. Food Sci. Technol., 46, 2103-2110. http://dx.doi.org/10.1111/j.1365-2621.2011.02722.x

Adhikari, K., Mustaphaa, A., Grun, I. U. (2003). Survival and metabolic activity of microencapsulated Bifidobacterium longum in stirred yogurt. J. Food Sci., 68, 275-281.

Al Otaibi, M., El Demerdash, H. (2008). Improvement of the quality and shelf life of concentrated yoghurt (Labneh) by the addition of some essential oils. African J. Microbiol. Res., 2, 156-161.

Amarita, F., Requenai, T., Tabordaz, G., Amigo, L., Pelaez, C. (2001). Lactobacillus casei and Lactobacillus plantarum initiate catabolism of methionine by transamination. J. Appl. Microbiol., 90, 971-978.

AOAC (2012). Official methods of analysis. $19^{\text {th }}$ ed., Gaithersburg, M.D., USA: Association of Official Analytical Chemists.

Axelsson, L. (2004). Lactic acid bacteria: Classification and physiology. In: S. Salminen, A. von Wright, A. Ouwehand (Eds.), Lactic acid bacteria: microbiological and functional aspects. New York: Marcel Dekker.

Castro, J. M., Tornadijo, M. E., Fresno, J., Sandoval, H. (2015). Biocheese: A food probiotic carrier. Biomed. Res. Int., 5, 1-12. http://dx.doi.org/10.1155/2015/723056

Champagne, C. P., Kailasapathy, K. (2008). Encapsulation of probiotics. In: N. Garti (Ed.), Controlled release technologies for targeted nutrition (pp. 344-369). Cambridge, UK: Wood Head Publ., CRC Press.

Claesson, M. J., van Sinderen, D., O'Toole, P. W. (2007). The genus Lactobacillus - a genomic basis for understanding its diversity. FEMS Microbiol. Lett., 269, 2228. http://dx.doi.org/10.1111/j.1574-6968.2006.00596.x

De Man, J. C., Rogosa, M., Sharp, M. E. (1960). A medium for the cultivation of lactobacilli. J. Appl. Bacteriol., 23, 130-136. https://doi.org/10.1111/j.1365-2672.1960. tb00188.x

Dinakar, P., Mistry, V. V. (1994). Growth and viability of Bifidobacterium bifidum in cheddar cheese. J. Dairy Sci., 77, 2854-2864. http://dx.doi.org/10.3168/jds. S0022-0302(94)77225-8

Ding, W. K., Shah, N. P. (2007). Acid, bile, and heat tolerance of free and microencapsulated probiotic bacteria. J. Food Sci., 72, 446-50. http://dx.doi.org/10.1111/j.1750-3841. 2007.00565.x

Dzigbordi, B., Adubofuor, J., Dufie W.-M. (2013). The effects of different concentrations of natamycin and the point of addition on some physicochemical and microbial properties of vanilla-flavored yoghurt under refrigerated condition. Int. Food Res. J., 20, 3287-3292.

El-Deib, S. M., Abd Rabo, F. H. R., Badran, S. M., Abd El-Fattah, A.M., Elshaghabee, F. M. F. (2012). The growth behavior and enhancement of probiotic viability in bioyoghurt. Int. Dairy J., 22, 44-47.

El-Gizawy, S. A., Olfat, S. B., Sharaf, O. M., El-Shafei, K., Fathy, F. A., El-Sayed, H. (2013). Effect of growth conditions on the production of exo-polysaccharides by microencapsulated Lactobacillus bulgaricus and use it to improve quality of Kareish cheese. J. Appl. Sci. Res., 9, 1097-1109.

El-Sayed, H. S., Kassem, J. M., El-Shafei, K., Assem, F. M., Sharaf, O. M. (2017). Comparative evaluation of the microencapsulation methods efficiency to protect 
El-Shafei, K., Elshaghabee, F. M. F., El-Sayed, H. S., Kassem, J. M. (2018). Assessment the viability properties of Lactobacillus casei strain using labneh as a carrier. Acta Sci. Pol. Technol. Aliment., 17(3), 267-276. http://dx.doi.org/10.17306/J.AFS.2018.0583

probiotic strains in simulated gastric conditions. Int. J. Biol. Pharm. Allied Sci., 3, 521-545.

El-Shafei, K., El-Sayed, H. S., Dabiza, N., Sadek, Z. I., Sharaf, O. M. (2015). The effect of microencapsulation on protection of isolated urease-producing streptococcus thermophilus against stress conditions. Res. J. Pharm. Biol. Chem. Sci., 6, 1573-1582.

Elshaghabee, F. M. F. (2016a) Viability of Bifidobacterium longum encapsulated in different capsule materials under simulated gastrointestinal conditions. Egypt. J. Dairy Sci., 44, 37-43.

Elshaghabee, F. M. F., Bockelmann, W., Meske, D., de Vrese, M., Walte, H.-G., Schrezenmeir, J., Heller, K. J. (2016b). Ethanol production by selected intestinal microorganisms and lactic acid bacteria growing under different nutritional conditions. Front. Microbiol., 7, 47-55. http://dx.doi.org/10.3389/fmicb.2016.00047

Fuller, R. (1992). Probiotics - the scientific basis. London: Chapman and Hall.

Gillian, Y. (2008). Symbiosis: The bacteria diet. Nat. Rev. Microbiol., 6, 174-175.

Gobbetti, M., De Angelis, M., Di Cagno, R., Fox, F. (2015). Pros and cons for using non-starter lactic acid bacteria (NSLAB) as secondary/adjunct starters for cheese ripening. Trends Food Sci. Technol., 45, 1-15. http://dx.doi. org/10.1016/j.tifs.2015.07.016

Godward, G., Kailasapathy, K. (2003). Viability and survival of free, encapsulated and co-encapsulated probiotic bacteria in yoghurt. Milchwissenschaft, 58, 396-399.

Hamdan, I. Y., Kunsman Jr, J. E., Deanne D. (1971). Acetaldehyde production by combined yogurt cultures. J. Dairy Sci., 54, 1080-1082.

Hanover, L. M., White, J. S. (1993). Manufacturing, composition, and applications of fructose. Am. J. Clin. Nutr. $58,724 \mathrm{~S}-732 \mathrm{~S}$

Iyer, C., Phillips, M., Kailasapathy, K. (2005). Release studies of Lactobacillus casei strain Shirota from chitosan-coated alginate-starch microcapsules in ex vivo porcine gastrointestinal contents. Lett. Appl. Microbiol., 41, 493-497. http://dx.doi.org/10.1111/j.1472-765X.2005.01778.x

Jayalalitha, V., Palani Dorai, R., Dhanalakshmi, B., Elango, A., Nasresh, K. C. (2011). Improving the viability of probiotics in yoghurt through different methods of encapsulation. Egypt. J. Dairy Sci., 39, 39-44.

Kailasapathy, K. (2006). Survival of free and encapsulated probiotic bacteria and their effect on the sensory properties of yoghurt. Food Sci. Technol., 10, 1221-1227. http://dx.doi.org/10.1016/j.lwt.2005.07.013

Kandler, O., Weiss, N. (1986). Genus Lactobacillus. In: P. H. A. Sneath, N. S. Mair, M. E. Sharpe, J. G. Holt (Eds),
Bergey's manual of systematic bacteriology $\left(9^{\text {th }}\right.$ ed., vol. 2, pp. 1063-1065). Baltimore: Williams and Wilkins.

Kleerebezem, M., Boekhorst, J., van Kranenburg, R., Molenaar, D., Kuipers, O. P., Leer, R., Siezen, R. J. (2003) Complete genome sequence of Lactobacillus plantarum WCFS1.PNAS, 100,1990-1995.https://doi.org/10.1073/ pnas. 0337704100

Klinkenberg, G., Lystad, K. Q., Levine, D. W., Dyrset, N. (2001). pH-controled cell release and biomass distribution of alginate-immobilized Lactococcus lactis subsp. lactis. J. Appl. Microbiol., 91, 705-714. https://doi. org/10.1046/j.1365-2672.2001.01420.x

Krasaekoopt, W., Bhandari, B., Deeth, H. (2004). The influence of coating materials on some properties of alginate beads and survivability of microencapsulated probiotic bacteria. Int. Dairy J., 14(8), 737-743. https://doi. org/10.1016/j.idairyj.2004.01.004

Lee, G. I., Jago, G. R. (1969). Methods for the estimation of acetaldehyde in cultured dairy products. Austr. J. Dairy Technol., 24, 181-190.

Maity, T. K., Kumar, R., Misra, A. K. (2008). Development of healthy whey drink with Lactobacillus rhamnosus, Bifidobacterium bifidum and Propionibacterium freudenreichii subsp. shermanii. Mljekarstvo, 58, 315-325.

Mandal, S., Hati, S., Puniya, A. K., Khamrui, K., Singh, K. (2014b). Enhancement of survival of alginate-encapsulated Lactobacillus casei NCDC 298. J. Sci. Food Agric., 94, 1994-2001. http://dx.doi.org/10.1002/jsfa.6514

Mandal, S., Puniya, A. K., Singh, K. (2006). Effect of alginate concentration on survival of microencapsulated Lactobacillus casei NCDC-298. Int. Dairy J., 16, 1190 1196. http://dx.doi.org/10.1016/j.idairyj.2005.10.005

Mayra-Makinen, A., Bigret, M. (1998). Industrial use and production of lactic acid bacteria. In: S. Salminen, A. V. Wright (Eds), Lactic acid bacteria microbiology and functional aspects (2nd ed., pp. 73-102). New York: Marcel Dekker.

Mohamed, S. H. S., Seleet, F. L., Azzat, B., Abd El Khalek, B., Fathy, F. A. (2015). Effect of wheat germ extract on the viability of probiotic bacteria and properties of labneh cheese. Res. J. Pharm. Biol. Chem. Sci., 6, 674-652.

Mohamed, S. H. S., Zaky, W. M., Kassem, J. M., Abbas, H. M., Salem, M. M. E., Said-Al Ahl, H. A. H. (2013). Impact of antimicrobial properties of some essential oils on cheese yoghurt quality. World Appl. Sci. J., 27, 497-507. http://dx.doi.org/10.5829/idosi.wasj.2013.27.04.13623

Mohammadi, R., Mortazavian, A. M. (2011). Review article: technological aspects of prebiotics in probiotic fermented milks. Food Rev. Int., 27, 192-212. http:// dx.doi.org/10.1080/87559129.2010.535235 
Nsabimana, C., Jiang, B., Kossah, R. (2005). Manufacturing, properties and shelf life of Labneh: a review. Int. J. Dairy Technol., 58, 129-137. http://dx.doi. org/10.1111/j.1471-0307.2005.00205.x

Pack, M. Y., Sandine, W. E., Elliker, P. R., Day, E. A., Lindsay, R. C. (1964). Owades and Jakovac method for diacetyl determination in mixed strain starters. J. Dairy Sci., 44, 15-26.

Rocha, D. M. U. P., Martins, J. L., Santos, T. S., Moreire, A. V. B. (2014). Labneh with probiotic properties produced from kefir: development and sensory evaluation. Food Sci. Technol., 34, 694-700. http://dx.doi. org/10.1590/1678-457x.6394

Saad, N., Delattre, C., Urdaci, M., Schmitter, J. M., Bressollier, P. (2013). An overview of the last advances in probiotic and prebiotic field. LWT - Food Sci. Technol., 50, 1-16. http://dx.doi.org/10.1016/j.lwt.2012.05.014

SAS (2004). SAS user's guide: Statistics. Ver. 6.04. $4^{\text {th }}$ ed., Cary, NC., USA: SAS Inst.

Shah, N. P. (2000). Probiotic bacteria: Selective enumeration and survival in dairy foods. J. Dairy Sci., 83, 894-907. http://dx.doi.org/10.3168/jds.S0022-0302(00)74953-8

Shah, N. P. (2004). Probiotics and prebiotics. AgroFood Ind. Hi-Tech., 27, 13-16.

Shewale, R., Sawale, P. D., Khedkar, C. D., Singh, A. (2014). Selection criteria for probiotics: a review. Int. J. Probiot. Prebiot., 9, 17-22.

Shi, L-E., Zhen-Hua, L., Li, D. T., Chen, H.-Y. (2013). Encapsulation of probiotic Lactobacillus bulgaricus in alginate-milk microspheres and evaluation of the survival in simulated gastrointestinal conditions. J. Food Eng., 117, 99-104. http://dx.doi.org/10.1016/j.jfoodeng. 2013.02.012

Siuta-Cruce, P., Goulet, J. (2001). Improving probiotic survival rates. Food Technol., 55, 36-42.
Swearingen, P. A., O’Sullivan, D. J., Warthesen, J. J. (2001). Isolation, characterization, and influence of native, nonstarter lactic acid bacteria on Cheddar cheese quality. J. Dairy Sci., 84, 50-59. http://dx.doi.org/10.3168/jds. S0022-0302(01)74451-7

Terzaghi, B. E., Sandine, W. E. (1975). Improved medium for lactic acid streptococci and their bacteriophages. Appl. Microbiol., 29, 807-813.

Tran, L. T., Yuen, V. G., McNeill, J. H. (2009). The fructosefed rat: a review on the mechanisms of fructose-induced insulin resistance and hypertension. Mol. Cell Biochem., 332, 145-159. http://dx.doi.org/10.1007/s11010-009-01 84-4

Tuomola, E., Crittenden, R., Playne, M., Isolauri, E., Sakminen, S. (2001). Quality assurance criteria for probiotic bacteria. Am. J. Clin. Nutr., 73, 393-398.

Van der Meulen, R., Makras, L., Verbrugghe, K., Adriany, T., De Vuyst, L. (2006). In vitro kinetic analysis of oligo-fructose consumption by Bacteroides and Bifidobacterium spp. indicates different degradation mechanisms. Appl. Environ. Microbiol., 72, 1006-1012. http://dx.doi. org/10.1128/AEM.72.2.1006-1012.2006

Van Hoorde, K., Van Leuven, I., Dirinck, P., Heyndrickx, M., Coudijzer, K., Vandamme, P., Huys, G. (2010). Selection, application and monitoring of Lactobacillus paracasei strains as adjunct cultures in the production of Goudatype cheeses. Int. J. Food Microbiol., 144, 226-235. http://dx.doi.org/10.1016/j.ijfoodmicro.2010.05.007

Zaręba, D., Ziarno, M., Ścibisz, I., Gawron, J. (2014). The importance of volatile compound profile in the assessment of fermentation conducted by Lactobacillus casei DN-114 001. Int. Dairy J., 35(1), 11-14. http://dx.doi. org/10.1016/j.idairyj.2013.09.009 